Bull. Fac. Agric., Cairo Univ., 63: 353-359 (2012).

\title{
EFFECT OF LATE PLANTING ON GRAIN YIELD OF SOME MAIZE HYBRIDS
}

(Received:10.10.2012)

\author{
By \\ M. M. M Hassan and Maha G. Balbaa \\ Maize Research Department, Field Crops Research Institute, Agriculture Research Center, Giza, Egypt
}

\begin{abstract}
This investigation was conducted at Nubaria Res. Stn. In 2010 and 2011 seasons to study the response of some maize hybrids to late planting dates. Eleven maize hybrids (SC10, SC122, SC128, SC129, SC164, SC166, SC167, SC168, TWC321, TWC324 and TWC329) were planted on July1, July15, Aug.1 and Aug.15. Results showed significant yield differences among the hybrids in their response to late planting. Delaying planting after July $15^{\text {th }}$ significantly increased the number of days from planting to $50 \%$ tasseling and silking but decreased plant and ear heights. Grain yield reduced with delaying planting from July1 to Aug.15. Growing maize in the period from July 15 to Aug.1 significantly increased leaf blight disease infection, while planting on Aug.15 showed significant decrease in disease infection compared to planting on the previous period. Single cross 10 surpassed all hybrids in grain yield (19.40 $\operatorname{ard} / \mathrm{fed})$ in the first season, while TWC 321 produced the highest grain yield $(20.36 \mathrm{ard} / \mathrm{fed})$ in the second one. On the other hand, SC128 was the most inferior in grain yield (13.44 ard/fed) in both seasons, while SC122 gave the lowest grain yield (15.78 ard/fed) in the second season. The interaction between hybrids and planting dates was significant for all studied traits, except ear height in the second season. This study indicated that SC10 maybe the most suitable maize hybrid for late plantings followed by TWC 321 and SC166.
\end{abstract}

Key words: hybrids, leaf blight, late plating, maize.

\section{INTRODUCTION}

In Egypt, in some areas farmers are used to plant maize late in the summer after harvest of some vegetable crops in the spring (March- April). Testing the effect of late planting on grain yield of maize hybrids is extremely important for such farmers. Late Planting time is one of the most important aspects of production management. Tanaka and Hara (1971) in Japan found that delay in planting reduced the length of the vegetative growth period, delayed silking and shortened the ripening period as well as reduced grain yield. Amer et al., 1991) in Egypt, reported that midJune planting produced the highest grain yield, whereas planting on mid-July decreased the number of days from planting to mid-silking, plant height and grain yield. Late Planting can affect yield through influencing seedling emergence, plant growth, pollination and maturity (Noormohammadi et al., 1997) in Iran. Crop planting in the suitable date results in good root development, increment of plant tolerance against stresses and finally increased grain yield (Dasilva et al., 1999). Grain yield is a complex character determined by several components which reflect positive or negative effects upon this trait .It is well known that late planting can result in low yield because the probability exists that unfavorable climatic conditions can occur during the growing season. Hassan (1999) in Egypt, indicated that delayed planting (July) significantly decreased the number of days from planting to $50 \%$ tasseling and silking, plant height, ear height and grain yield. Norwood (2001) in U.S.A, revealed that early planting (mid-April) decreased yield and water use efficiency. The highest yield and water use efficiency were obtained in May planting. Nielson et al., (2002) in U.S.A, reported that delayed planting (June) shortens the effective growing season for corn, increasing the risk of exposure to lethal temperatures late in the season before grain maturation. Wiatrak et al., (2004) in U.S.A, found that delayed corn planting in U.S southeast often results in insect and disease problems and the highest grain yield(16.1 t ha $\left.{ }^{-1}\right)$ was obtained when planting was in March and April, while the lowest yields $\left(6.1 \mathrm{t} \mathrm{ha}^{-1}\right.$ and $4.5 \mathrm{t}$ $\mathrm{ha}^{-1}$ ) were obtained when planting was in July and 
August, respectively. Khalil (2007) in Egypt, stated that yield of the studied hybrids was significantly decreased by delay planting from May 25 to June 25. El-Galfy et al., (2009) in Egypt, indicated that late planting dates (JulyAugust) significantly decreased the number of days from planting to $50 \%$ tasseling and silking, plant and ear heights. Grain yield was reduced by 33,24 , and $29 \%$ in the first and second seasons and also in the combined analysis over both years, respectively, when planting date was delayed from July1 to Aug.15. Late planting (July-August) normally exhibits higher leaf blight disease infection compared to normal season (May- June) planting. Bair et al., (1990) and Tefferi et al., (1996), found that Leaf blight disease reduced yields of susceptible hybrids. Khalifa and zein ElAbdeen (2000) in Egypt, indicated that late planting increased infection with leaf blight.

The objective of this study was to find out the most suitable maize hybrid (s) which perform well under late planting conditions.

\section{MATERIALS AND METHODS}

A field experiment was conducted at Nubaria Res. Stn., Egypt in 2010 and 2011 seasons to study the response of some maize hybrids to late planting dates. Four different planting dates were practiced i.e., July1, July15, Aug.1 and Aug.15. Every planting date was carried out in a separate trial included eleven maize hybrids; SC10, SC122, SC128, SC129, SC164, SC166, SC167, SC168, TWC321, TWC324, and TWC 329 . Experimental design was randomized complete blocks arranged in incomplete blokes with four replications, where replications were nested within planting dates. Experimental plot consisted of two rows $6 \mathrm{~m}$ in length, $80 \mathrm{~cm}$ in width and hills were spaced 20 $\mathrm{cm}$ within the row. All cultural practices for maize production were applied as recommended. Twenty $\mathrm{m}^{3} /$ feddan of a farm manure was added to all experimental units before planting in both seasons. Thirty $\mathrm{kg} \mathrm{p}_{2} \mathrm{O}_{5}$ and $24 \mathrm{~kg} \mathrm{~K}_{2} \mathrm{O} /$ feddan were added during soil preparation. Nitrogen fertilizer $(120 \mathrm{~kg} \mathrm{~N})$ was added in the form of ammonium nitrate $(33.5 \% \mathrm{~N})$. Nitrogen was split into two equal doses. Studied traits were the number of days from planting to $50 \%$ tasseling (pollen shedding) and silking, plant height, ear height, grain yield, and leaf blight disease infection. Plant and ear heights $(\mathrm{cm})$ were measured from ground surface to the top of tassel and the highest ear-bearing node, respectively. Grain yield (ard/fed) was estimated from the two rows of each experimental plot and was adjusted on the basis of $15.5 \%$ grain moisture. Percentage of leaf blight disease infection under natural infection conditions was measured 15 days after mid-silking on 2011 season and the data were transformed before statistical analysis according to $\log (\mathrm{x})$. Data were statistically analyzed according to Steel and Torrie (1980). Bartlett's test of homogeneity was used according to Bartlett (1937).

\section{RESULTS AND DISCUSSION}

Bartlett's test of homogeneity of yield variance was performed . Results revealed that chi-square value was 15.3 with probability $>$ chi-square $=<$ 0.00001 indicating that combining ability analysis between years is not valid.

\subsection{Effect of planting dates}

Data presented in Table (1) revealed that all studied traits were significantly affected by delaying planting dates in both seasons. It is noticed that planting in the first of July gave the lowest number of days from planting to $50 \%$ tasseling and silking, while mid of August gave the highest number of days to 50\% tasseling and silking in the two growing seasons. Therefore, the general trend showed that the number of days to $50 \%$ tasseling and silking increased clearly by delaying planting.

Results in Table (1) showed also that delaying planting significantly decreased plant and ear heights in both seasons. The shortest plants and the lowest ear placement were associated with the latest planting date (August) compared with early planting dates. This reduction in plant and ear height might be attributed to the reduction in length of the vegetative growth period. Also, other factors such as temperature, light duration and photoperiod as well as day and night temperature differences could be taken in consideration in this respect. These results are in accordance with those obtained by Ibrahim et al., (1995), Aly (1998), Gouda et al., (1998), Sherif et al., (2005), and ElGalfy et al., (2009). Leaf blight disease infection under natural infection conditions was recorded only in 2011 in planting dates from Jul.15 to Aug.15. Results showed that July 15 and Aug.1 planting resulted in the highest disease infection (26.1 and $29.5 \%$, respectively) compared to Aug. 15 planting (18.4\%), which may indicate that planting in the period from Jul.15 to Aug.1 favors high infection with this disease. The esults need to be confirmed under artificial infection conditions. Khalifa and Zein El-Abedeen (2000) found that late planting (mid-July) increased infection with leaf blight under surface and sprinkler irrigation 
Table (1): Effect of late planting dates on days to $50 \%$ tasseling and silking, plant and ear eight $(\mathrm{cm})$, grain yield $\left(\operatorname{ard~fed~}^{-1}\right)$, and leaf blight infection in 2010 and 2011 seasons.

\begin{tabular}{|c|c|c|c|c|c|c|c|c|c|c|c|c|}
\hline \multirow{2}{*}{$\begin{array}{l}\text { Planting } \\
\text { dates }\end{array}$} & \multicolumn{2}{|c|}{$\begin{array}{c}\text { Days to } 50 \% \\
\text { tasseling(d) }\end{array}$} & \multicolumn{2}{|c|}{$\begin{array}{c}\text { Days to } 50 \% \\
\text { silking(d) }\end{array}$} & \multicolumn{2}{|c|}{$\begin{array}{c}\text { Plant height } \\
(\mathrm{cm})\end{array}$} & \multicolumn{2}{|c|}{$\begin{array}{l}\text { Ear height } \\
\text { (cm) }\end{array}$} & \multicolumn{2}{|c|}{$\begin{array}{c}\text { Grain yield (ard } \\
\text { / fed) }\end{array}$} & \multicolumn{2}{|c|}{$\begin{array}{c}\text { Leaf blight * } \\
\text { infection }\end{array}$} \\
\hline & 2010 & 2011 & 2010 & 2011 & 2010 & 2011 & 2010 & 2011 & 2010 & 2011 & Org.t+ & Trans.++ \\
\hline July1 & 58.4 & 58.1 & 60.5 & 59.9 & 188 & 202 & 98 & 104 & 22.36 & 24.63 & - & - \\
\hline July15 & 62.5 & 62.2 & 64.4 & 64.9 & 174 & 196 & 87 & 100 & 14.45 & 20.68 & 26.1 & 1.38 \\
\hline Aug.1 & 62.8 & 64.0 & 65.8 & 67.3 & 176 & 183 & 84 & 91 & 13.77 & 13.77 & 29.5 & 1.41 \\
\hline Aug.15 & 65.5 & 65.1 & 69.1 & 69.8 & 170 & 173 & 78 & 82 & 12.94 & 12.01 & 18.4 & 1.13 \\
\hline LSD 0.05 & 0.8 & 0.4 & 0.6 & 0.7 & 5.0 & 4.4 & 2.7 & 3.8 & 1.25 & 2.39 & 5.08 & 0.27 \\
\hline
\end{tabular}

Table (2): Average grain yield ,growth characters and leaf blight infection of some maize hybrids over 4 late planting dates in 2010 and 2011.

\begin{tabular}{|c|c|c|c|c|c|c|c|c|c|c|c|c|}
\hline \multirow[t]{2}{*}{ Hybrid } & \multicolumn{2}{|c|}{$\begin{array}{c}\text { Days to } 50 \% \\
\operatorname{tasseling}(d)\end{array}$} & \multicolumn{2}{|c|}{$\begin{array}{l}\text { Days to } 50 \% \\
\text { silking(d) }\end{array}$} & \multicolumn{2}{|c|}{ Plant height $(\mathrm{cm})$} & \multicolumn{2}{|c|}{ Ear height $(\mathrm{cm})$} & \multicolumn{2}{|c|}{$\begin{array}{c}\text { Grain yield (ard / } \\
\text { fed) }\end{array}$} & \multicolumn{2}{|c|}{ Leaf blight } \\
\hline & 2010 & 2011 & 2010 & 2011 & 2010 & 2011 & 2010 & 2011 & 2010 & 2011 & Org & Trans \\
\hline SC 10 & 63.6 & 62.9 & 66.3 & 66.2 & 185 & 197 & 95 & 97 & 19.40 & 19.23 & 26.7 & 1.36 \\
\hline SC 122 & 63.5 & 63.1 & 66.8 & 66.8 & 174 & 190 & 87 & 96 & 14.14 & 15.78 & 34.2 & 1.48 \\
\hline SC128 & 61.2 & 62.6 & 64.3 & 66.1 & 174 & 188 & 85 & 93 & 13.44 & 16.39 & 21.7 & 1.27 \\
\hline SC129 & 60.8 & 61.0 & 63.1 & 63.8 & 185 & 190 & 92 & 95 & 16.55 & 18.77 & 15.8 & 1.18 \\
\hline SC164 & 61.6 & 62.6 & 64.2 & 65.5 & 174 & 179 & 90 & 89 & 15.67 & 15.99 & 25.8 & 1.37 \\
\hline SC166 & 61.5 & 61.0 & 64.1 & 63.6 & 173 & 184 & 85 & 93 & 17.06 & 18.93 & 24.2 & 1.32 \\
\hline SC 167 & 61.9 & 62.2 & 64.6 & 64.9 & 173 & 181 & 81 & 93 & 16.56 & 17.25 & 25.8 & 1.23 \\
\hline SC168 & 63.1 & 61.8 & 65.9 & 64.6 & 173 & 182 & 79 & 91 & 15.60 & 17.91 & 30.0 & 1.45 \\
\hline TWC321 & 62.4 & 63.2 & 64.8 & 66.1 & 174 & 196 & 84 & 97 & 16.37 & 20.36 & 21.7 & 1.29 \\
\hline TWC324 & 63.2 & 63.0 & 65.6 & 66.3 & 183 & 196 & 89 & 98 & 14.74 & 18.77 & 24.2 & 1.23 \\
\hline TWC329 & 62.6 & 62.5 & 64.8 & 66.1 & 181 & 192 & 87 & 97 & 15.16 & 16.14 & 21.7 & 1.19 \\
\hline L.S.D 0.05 & 0.6 & .05 & 0.5 & 0.7 & 4.6 & 4.4 & 4.1 & 3.6 & 1.13 & 1.37 & 9.7 & 0.24 \\
\hline
\end{tabular}


systems.

Delaying planting date from Jul.1 to Aug.15 significantly reduced grain yield by $42.13 \%$ and $51.24 \%$ in both seasons. Results showed that grain yield reached its maximum at July 1 planting in both years (22.36 and $24.63 \mathrm{ard} / \mathrm{fed})$, respectively.
In contrast, delaying planting to Aug.15 gave the lowest grain yield (12.94 and $12.01 \mathrm{ard} / \mathrm{fed}$ ) in the two years, respectively. It could be noticed that delaying planting from Aug.1 to mid Aug. had no significant reduction in grain yield in both seasons (Table 1). These results are in accordance with

Table (3): Effect of interaction between late planting date and maize hybrids on the studied traits in 2010 and 2011 seasons.

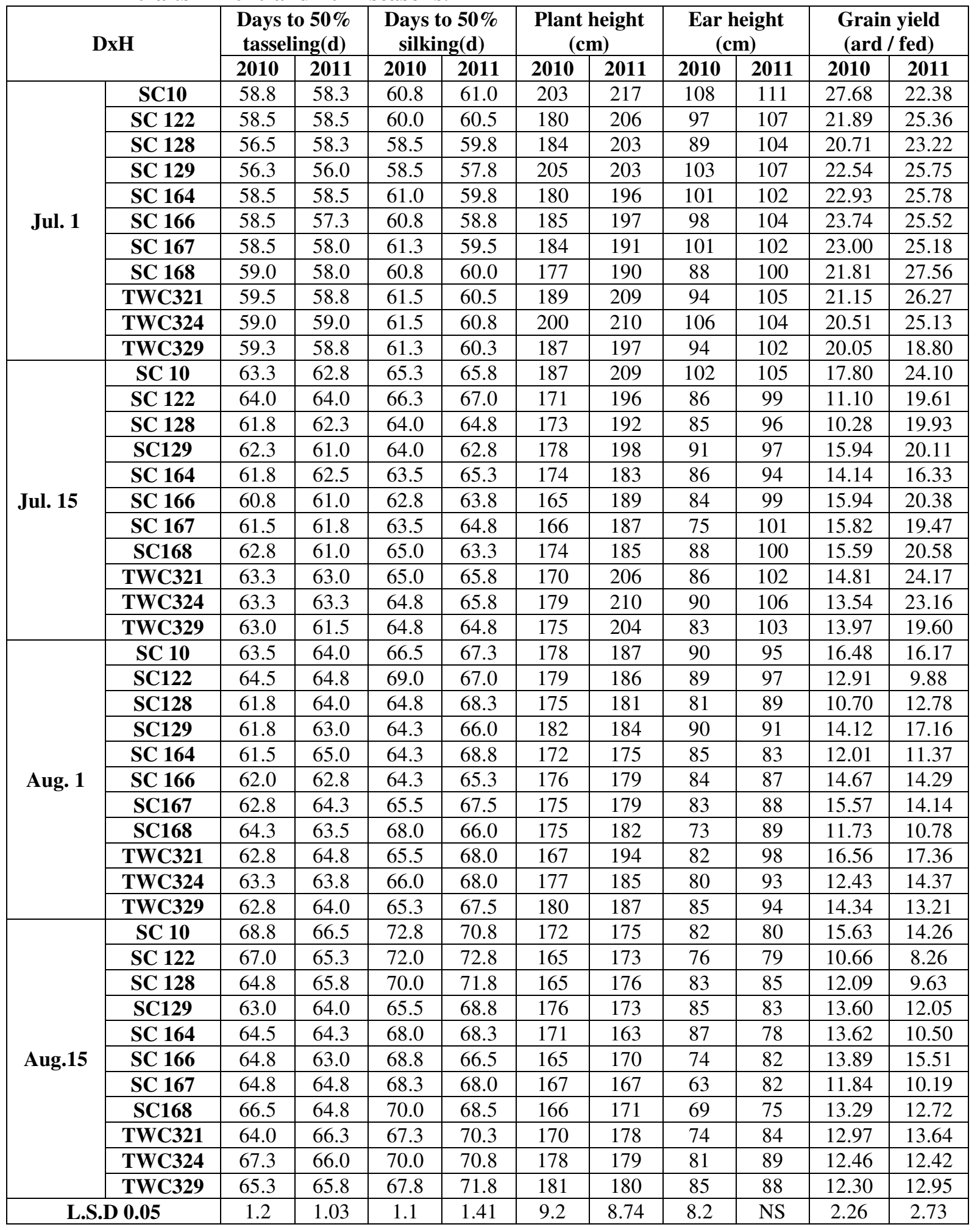


those obtained by Amer et al., (2001) who found that delaying planting from June 16 to July 17 caused grain yield (ard/fed) reduction.

\subsection{Hybrid Effect}

The obtained results (Table 2) showed significant differences among the tested hybrids for all the studied traits. Considering the number of days from planting to $50 \%$ tasseling and silking, SC129 was the earliest hybrid in the two seasons but the difference between SC166 and SC129 was not significant in 2011 season, while SC10, SC 122, TWC321, and TWC 324 were the latest in flowering in both seasons, except for TWC 321 in the first season.

The data presented in Table (2) revealed that the differences among the tested hybrids were significant in the two growing seasons. Plant height ranged from $173 \mathrm{~cm}$ (SC166, SC167 and SC168) to $185 \mathrm{~cm}$ (SC10 and SC129) in the first season and from $179 \mathrm{~cm}$ (SC164) to $197 \mathrm{~cm}$ (SC10) in the second season. Therefore, SC10 was the tallest hybrid in both seasons, whereas SC164, SC167 and SC168 had the shortest plants in both seasons. Single cross 168 had the shortest ear height in the two seasons, while SC10 had the highest ear placement in both seasons. It could be noticed that SC10 had the tallest plants and the highest ear height in both seasons. In contrast, SC164, SC167 and SC168 had the shortest plants and SC168 had the shortest ear height in both seasons, respectively.

Concerning grain yield, SC10 surpassed all hybrids in 2010 while TWC 321 gave the highest grain yield in the second season. On the other hand, the lowest grain yield was obtained by SC128 in the first season and both $\mathrm{SC} 122$ and SC164 in the second season (Table 2). Significant hybrid differences among maize hybrids regarding grain yield and its attributes were realized by Khedr et al., (1990), Gouda et al., (1998), Khalil (2007) and El-Galfy et al., (2009).

\subsection{Leaf blight infection}

Regarding the response of hybrids to leaf blight disease infection under late planting natural conditions , SC122 and SC168 had the highest infection (34.2 and $30 \%$, respectively), while SC129 had the lowest leaf blight infection (15.8 $\%)$. Khalifa and Zein El-Abedeen (2000) showed that maize genotypes varied considerably regarding their resistance to leaf blight disease. Welz and Geiger (2000) indicated that infections with turcicum leaf blight were affected by climatical changes.

\subsection{Hybrid $x$ late planting date interaction effect}

Interaction effects of planting date and maize hybrids on grain yield were significant as shown in Table 3. Concerning July $1^{\text {st }}$ planting date, SC10 significantly surpassed all hybrids (27.68 $\operatorname{ard} /$ fed) in the first year, while SC168 had the highest grain yield(27.56 ard/fed) in the second year. On the second planting date (July $15^{\text {th }}$ ) in 2010 the highest yield was attained by SC10 (17.80 ard/fed), while in 2011 TWC321 was the highest in yield (24.17 ard/fed).

In the third planting date (August $1^{\text {th }}$ ), in 2010 the highest grain yield was obtained from SC10 and TWC321 (16.48, $16.56 \mathrm{ard} / \mathrm{fed}$, respectively) while, SC129 and TWC 321 gave the highest yield (17.16 and $17.36 \mathrm{ard} / \mathrm{fed}$ ) in the second season. On mid-Aug. planting, SC10 and SC166 gave the highest grain yield (15.63 and 13.89 ard/fed) in 2010 and (14.26 and $15.51 \mathrm{ard} / \mathrm{fed})$ in 2011, respectively.

Finally, it could be concluded across the 4 late planting dates that $\mathrm{SC} 10$ was the most appropriate maize hybrid for late planting followed by TWC321 at Nubaria location. Response of maize hybrids to different planting dates was not similar, since SC129 produced high yield in planting dates of $1^{\text {st }}$ July and $1^{\text {st }}$ August, while SC166 gave high yield when planted either on $1^{\text {st }} \mathrm{July}$ or $15^{\text {th }}$ August, whereas TWC 324 produced high yield on Jul. $1^{\text {st }}$ and Jul.15. The interaction among hybrids and late planting dates differed from one season to another (Table 3).

\section{REFERENCES}

Aly A. A. (1998). Response of some introduced maize inbred lines to planting dates. Zagazig J. Agric. Res. Vol. 25 (2): 211-221.

Amer E. A. El-Shenawy A. A. and Mosa H. E. (2001). Influences of planting dates and population densities under artificial and natural infections of common smut disease on some maize varities. J. Agric. Sci. Mansoura Univ., 26(8): 4673- 4679.

Amer S. M., Faisal R. I. I., Younis M. A. and Gouda,A.Sh. (1991). Response of some maize inbred lines to planting dates. Egypt.J.Appl.Sci. 6(10):277-284.

Bair W J., Gahen H.C. and Ayers J. E.(1990): Effect of time and rate of $\mathrm{N}$ side dress application on northern corn leaf blight severity and the associated yield loss. J.Prod. Agric. 3 : 44-49.

Bartlett M.S.(1937).Properties of sufficiency and statistical tests Proc of the Royal Statistical Society, Series A, 160, 268-282. 
Dasilva P. R. F., Argenta G. and Rezera F. (1999). Response of irrigated corn hybrids to plant density in three sowing dates, Literature update on maize, CIMMYT. 5 (4):5.

El-Galfy A. M. K., Abdel-Azem M. E. M. and ElMekser Hoda Kh. A. (2009). Response of some maize hybrids to late planting dates. Annals of Agric. Sci., Moshtohor, 47(2): 121-127.

Gouda A. Sh., Sultan M. A. and El-Zeir F. A. (1998). Response of some newly released white and yellow maize hybrids to planting dates. J. Agric. Sci., Mansoura Univ., 23 (3): 1013-1019.

Hassan M. M. M. (1999). Effect of planting dates on the response of the hybrids maize to nitrogen fertilization.M.Sc.Thesis,Fac.of Agric., Al-Azhar Univ. Egypt.

Ibrahim M. E., Esmail S.E. and Nawar A. A. (1995). Varietal response to nitrogen level and planting date and determination of the dependence structure in yellow maize yield using factor analysis. Zagazig J. Agric. Res. 22( 2):329-347.

Khalifa K.I. and Zein El-Abedeen A. (2000). Turcicum leaf blight resistance in some Egyptian maize genotypes under surface and sprinkler irrigation systems. Egypt. J. Appl. Sci.15 (12): 410- 421.

Khalil M. A. G. (2007). Response of some white maize promising hybrids to planting datesand nitrogen fertilization. Ph. D. Thesis, Fac. of Agric., Kafr El-Sheikh Univ., Egypt.

Khedr E.S.F., Matta S. E., Mahgoub G. M. and Sadek S. E. (1990). Effect of planting dates on growth and yield of some maize hybrids. Egypt. J. Appl. Sci. 5(8):792-800.

Nielson R. L., Thomison P. R., Brown G. A., Halter A. L. and Kirby L. W. (2002). Delayed planting effects on flowering and grain maturation of dent corn. U.S. A,
Agron. J., Vol. 94(3): 549-558.

Noormohammadi Q., Siadat S .E. and Kashani E. (1997). Agronomy: First Volume: Cereal, $4^{\text {th }}$ edition, .Shahid Chamra Univ. Press, Ahvaz, Iran, p. 446.

Norwood C. A. (2001). Planting date, hybrid maturity and plant population Effects on soil water depletion, water use and yield of dryland corn. U.S.A. Agron.J.,Vol.93 (5):1034-1042.

Sherif S. A., Zohary A. A. and Ibrahim S. T. (2005). Effect of planting dates and densities of maize intercropped with groundnut on growth, yield and yield components of both crops. Arab Univ. J .Agric. Sci., Ain Shams Univ. Cairo,13 (3): 771- 791.

Steel R. G. D. and Torrie J. H. (1980). Principles and procedures of statistics A biometrical approach $3^{\text {rd }}$.ed., Mc Graw- Hill Book Company, New York.

Tanaka A. and Hara T. (1971). Studies on the nutiophysiology of the maize plants .10: Grain Yields as affected by planting dates. Nippon Dojohiryogaku Zasshi, 42: 435-438. (C.F. Field Crop Abst. 27:5545, 1974).

Tefferi A. A., Hulluka M. and Welz H. G. (1996). Assessment of damage and grain yield loss in maize caused by northern leaf blight in Western Ethiopia. Zeitschrift fur pflanzen krankheiten und pflanzen schutz. 103: 353363.

Welz H.G. and Geiger H.H.(2000). Genes for resistance to northern corn leaf blight in diverse maize populations. Pl. Breed. 119: $1-14$.

Wiatrak P.J., Wright D. L., Mariois J. J. and Sprenkel R. (2004). Corn hybrids for late planting in the U.S Southeast. Agron. J.,Vol. 96(4):1118-1124.

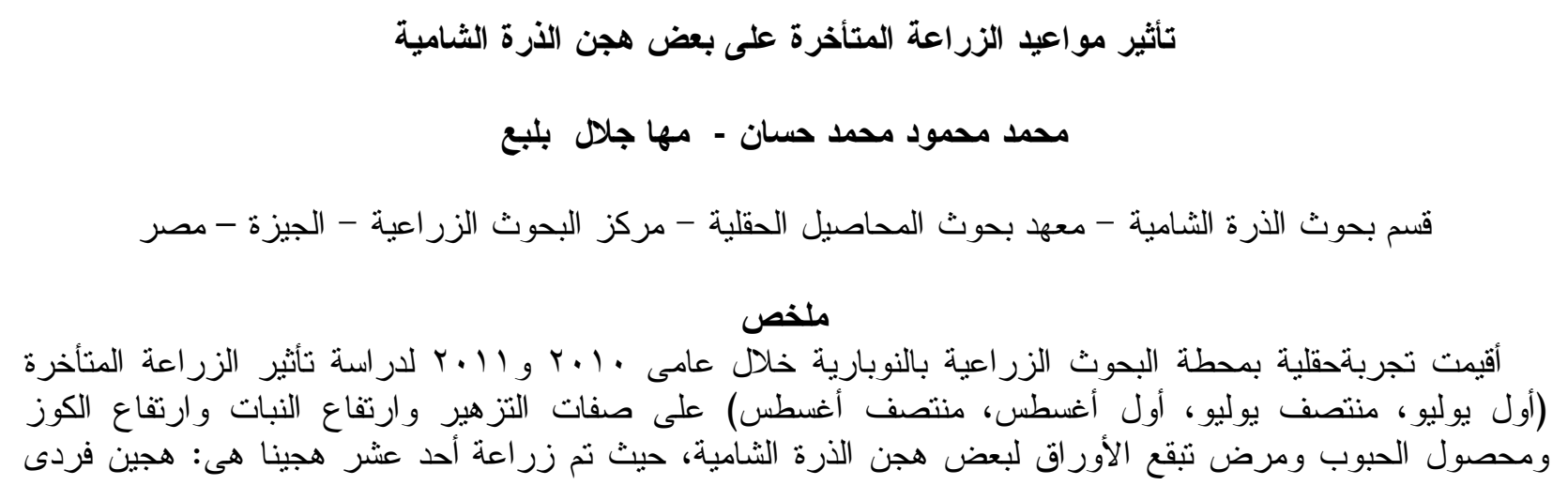




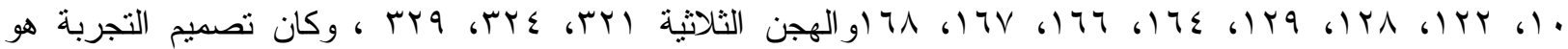

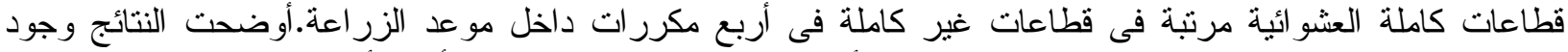

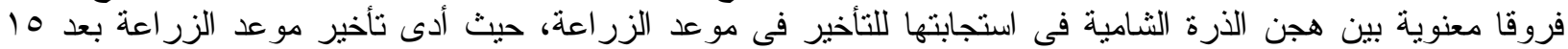

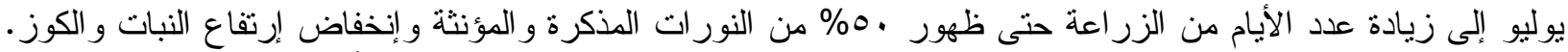

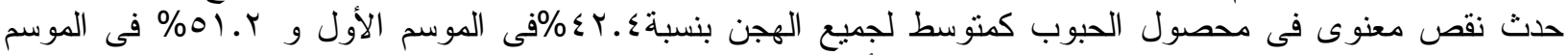

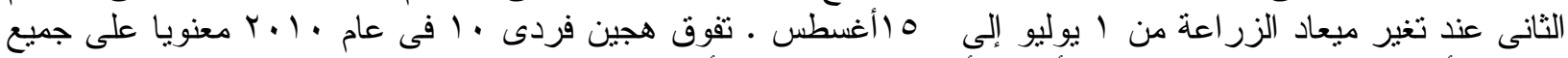

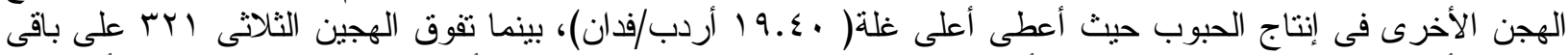

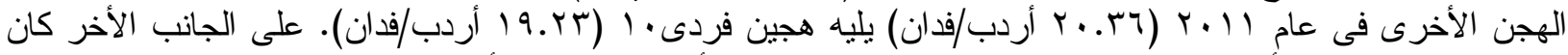

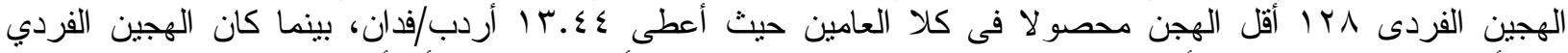

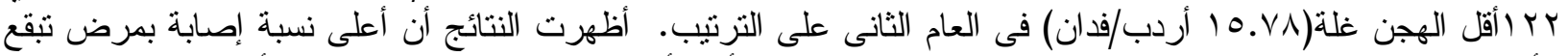

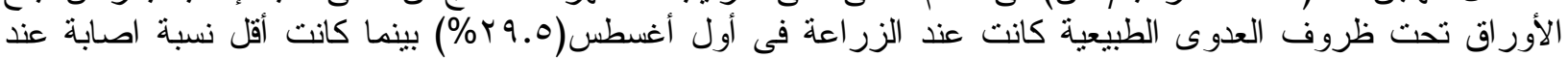

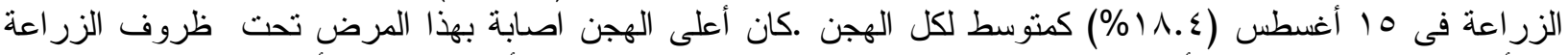

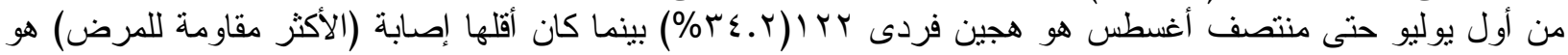

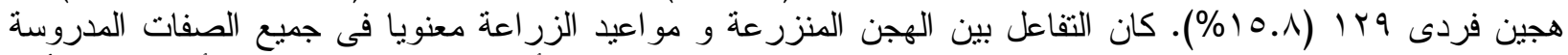

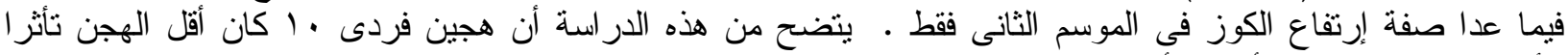

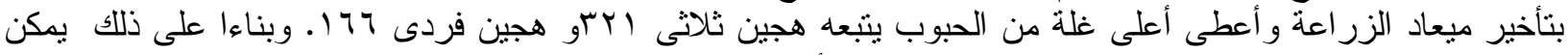

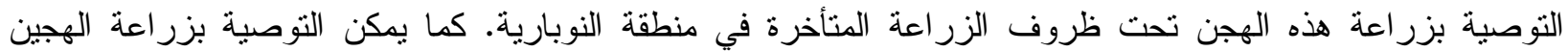

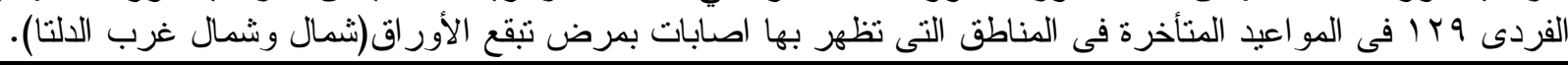

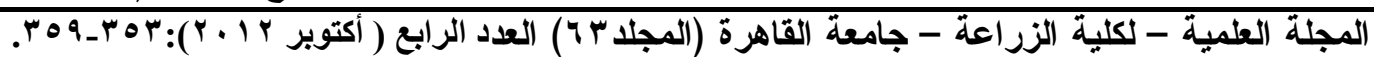

